\title{
Activity of Javanese Ginger, Turmeric, Garlic, and Pomegranate Flower on LDL-C and Total-C on Dyslipidemia Model Rats
}

\author{
Larissa, ${ }^{1}$ Penny Setyawati Martioso, ${ }^{1}$ Diana Krisanti Jasaputra ${ }^{2}$ \\ ${ }^{1}$ Department of Clinical Pathology, Faculty of Medicine, Universitas Kristen Maranatha, Bandung, Indonesia, \\ ${ }^{2}$ Department of Pharmacology, Faculty of Medicine, Universitas Kristen Maranatha, Bandung, Indonesia
}

\begin{abstract}
High levels of LDL cholesterol are risk factors for coronary heart disease. Different types of medicinal plants have hypolipidemic effects. The study aimed to compare the potential of Javanese ginger ethanol extract, turmeric, garlic, and pomegranate flowers with rosuvastatin on levels of LDL cholesterol (LDL-C) and total cholesterol (total-C) male Wistar rats dyslipidemia models. This experimental laboratory research was conducted in Maranatha Animal Research Laboratory Bandung and was carried out in January-December 2020. The experimental animals were divided into six groups $(n=5)$ : the control group, the Javanese ginger group, the turmeric group, the garlic group, the pomegranate flower group, and the comparison control group. The induction given to experimental animals was administering vitamin D3, a high-fat diet, and propylthiouracil for 14 days. The results showed that the administration of $175 \mathrm{mg} / \mathrm{kg} \mathrm{BW}$ of garlic ethanol extract (-44.85\%), pomegranate flowers $(-58.74 \%)$, and rosuvastatin $(-40.00 \%)$ reduced LDL-C compared to control (p<0.05). The administration of $175 \mathrm{mg} / \mathrm{kg}$ BW of Javanese ginger ethanol extract $(-15.16 \%)$, turmeric $(-14.02 \%)$, garlic $(-22.80 \%)$, pomegranate flower $(-65.24 \%)$, and rosuvastatin $(-18.70 \%)$ reduced total-C compared to controls $(\mathrm{p}<0.05)$. The conclusion is that garlic and pomegranate flowers lowered LDL-C, while Javanese ginger, turmeric, garlic, and pomegranate flowers reduced total-C.
\end{abstract}

Keywords: Garlic, Javanese ginger, LDL-C, pomegranate flower, total-C, turmeric

\section{Aktivitas Temulawak, Kunyit, Bawang Putih, dan Bunga Delima terhadap K-LDL dan K-Total pada Tikus Model Dislipidemia}

\begin{abstract}
Abstrak
Kadar kolesterol LDL yang tinggi adalah faktor risiko penyakit jantung koroner. Berbagai jenis tanaman obat memiliki efek hipolipidemik. Penelitian ini bertujuan membandingkan potensi ekstrak etanol temulawak, kunyit, bawang putih, dan bunga delima dengan rosuvastatin pada kadar kolesterol LDL (K-LDL) dan kolesterol total (K-total) tikus Wistar jantan model dislipidemia. Penelitian laboratorium eksperimental ini dilakukan di Laboratorium Penelitian Hewan Maranatha Bandung dan dilakukan pada Januari-Desember 2020. Hewan coba dibagi menjadi enam kelompok $(\mathrm{n}=5)$, yaitu kelompok kontrol, kelompok temulawak, kelompok kunyit, kelompok bawang putih, kelompok bunga delima, dan kelompok pembanding. Induksi yang diberikan kepada hewan coba adalah pemberian vitamin D3, pakan lemak tinggi, dan propyltiouracil selama 14 hari. Hasil penelitian menunjukkan bahwa pemberian $175 \mathrm{mg} /$ kgBB ekstrak etanol bawang putih $(-44,85 \%)$, bunga delima $(-58,74 \%)$, dan rosuvastatin $(-40,00 \%)$ mengurangi K-LDL dibanding dengan kontrol ( $\mathrm{p}<0,05)$. Pemberian $175 \mathrm{mg} / \mathrm{kgBB}$ ekstrak etanol temulawak $(-15,16 \%)$, kunyit $(-14,02 \%)$, bawang putih $(-22,80 \%)$, bunga delima $(-65,24 \%)$, dan rosuvastatin $(-18.70 \%)$ mengurangi K-total dibanding dengan kontrol ( $\mathrm{p}<0,05)$. Kesimpulannya, bunga bawang putih dan delima menurunkan K-LDL, sedangkan temulawak, kunyit, bawang putih, dan bunga delima menurunkan K-total.
\end{abstract}

Kata kunci: Bawang putih, bunga delima, K-LDL, K-total, kunyit, temulawak

Received: 20 March 2021; Revised: 4 August 2021; Accepted: 6 August 2021; Published: 31 August 2021 


\section{Introduction}

The number one cause of death in the world, according to WHO, is cardiovascular disease which causes the death of 17.9 million people each year. Cardiovascular diseases include coronary heart disease, blood vessel disease, and stroke. ${ }^{1}$ Cardiovascular disease occurs because of the atherosclerosis process. The process of atherosclerosis begins with the formation of plaque on the walls of blood vessels. This plaque can grow to be large and cause narrowing of the arteries and cause blockage. Blockage of these blood vessels can cause a heart attack or stroke. Cardiovascular disease has several risk factors, non-modifiable risk factors, and modifiable risk factors. Non-modifiable risk factors for cardiovascular disease that cannot change include genetics and previous disease history. The other side modifiable risk factors can be changed, such as lipid profile levels, blood glucose levels, obesity, smoking habits, and high blood pressure. Several studies have shown hypercholesterolemia, and elevated LDL cholesterol (LDL-C) levels have shown a positive correlation with an increased risk of coronary heart disease.

Coronary heart disease (CHD) and stroke are estimated to cause more than 470,000 deaths each year in Indonesia. The five main risk factors that can be changed are smoking, hypertension, diabetes, increased total cholesterol (total-C), and being overweight. ${ }^{2}$ Dyslipidemia is a major risk factor for coronary heart disease in a patient with type 2 diabetes. Dyslipidemia includes an increase in LDL-C and total-C. The drugs such as statins are directly associated with a reduced risk of cardiovascular disease. ${ }^{3}$

Traditional Indonesian medicines can overcome hypercholesterolemia, including Guazuma ulmifolia leaves, Cassia senna leaves, Sonchus arvensis leaves, Camellia sinensis leaves, Curcumaxanthorrhiza rhizomes, Curcuma longa rhizomes, and Phyllanthus niruri. ${ }^{4}$ Some other agents used to inhibit cholesterol increase include rice bran, dragon fruit, soy powder, and oyster mushrooms..$^{5-7}$ In addition, traditional medicines that can be used for hypercholesterolemia are garlic and pomegranate flowers.

The study aimed to compare the potential of Javanese ginger ethanol extract, turmeric, garlic, and pomegranate flowers with rosuvastatin on levels of LDL cholesterol (LDL-C) and total cholesterol (total-C) male Wistar rats dyslipidemia models.

\section{Methods}

This study used male Wistar rats aged eight weeks with an average body weight of 150-200 grams obtained from the Faculty of Pharmacy Science and Technology, Institut Teknologi Bandung. The research was conducted in January-December 2020 at the Maranatha Animal Research Laboratory, Bandung. The Research Ethics Committee of the Faculty of Medicine, Universitas Kristen Maranatha Bandung, approved the study (Protocol Number: 144/KEP/X/2020).

This experimental laboratory research design used a randomized control group with male Wistar rats divided into six groups $(n=5)$. In addition, groups were divided into control groups, the Javanese ginger ethanol extract group, the turmeric ethanol extract group, the garlic ethanol extract group, pomegranate flowers, and the comparator control group. The data measured were LDL-C levels and total-C levels in the treatment group and were analyzed using the one-way ANOVA analysis method and LSD test with alpha $=0.05$.

The experimental animals were adapted for seven days and then induced single-dose vitamin D3 140,000 IU/200 g orally before intervention with standard feeding and distilled water ad libitum. ${ }^{8}$ The experimental animals were given high-fat feed (HFF) and drinking water with $0.01 \%$ propylthiouracil (PTU) for 14 days. The experimental animals were randomly assigned to six groups $(n=5)$ with 14 days of treatment. Each treatment was given with a volume of $2 \mathrm{~mL}$ orally using an oral sonde: Group 1: given CMC 1\% and HFF and water with $0.01 \%$ PTU for 14 days; Group 2: Javanese ginger ethanol extract at a dose of $175 \mathrm{mg} / \mathrm{kg} \mathrm{BW}$ orally and HFF and water with 0.01\% PTU for 14 days; Group 3: $175 \mathrm{mg} /$ $\mathrm{kg}$ BW turmeric ethanol extract orally, HFF, and water with $0.01 \%$ PTU for 14 days; Group 4: 175 $\mathrm{mg} / \mathrm{kg}$ BW garlic ethanol extract orally, HFF and water with 0.01\% PTU for 14 days; Group 5: 175 $\mathrm{mg} / \mathrm{kg}$ BW pomegranate flower ethanol extract of dose of orally, HFF, and water with $0.01 \%$ PTU for 14 days; and Group 6: rosuvastatin orally and PLT with water with $0.01 \%$ PTU for 14 days.

On the fifteenth day, after receiving treatment for 14 days, blood serum was taken from the infraorbital veins. 


\section{Results}

The results in the form of LDL-C levels after 14 days of treatment were presented in Figure 1. Data on the percentage reduction in LDL-C in the treatment group were tested by one-way ANOVA and obtained a $\mathrm{p}$ value $<0.05$. It means that at least there was a pair of treatment groups that have a significant difference.

Table 1 showed that garlic $(-44.85 \%)$ and pomegranate flowers $(-58.74 \%)$ lowered LDL-C compared to the control with a significant difference. The potential of pomegranate flowers $(-58.74 \%)$ in lowering LDL-C was better than rosuvastatin $(-40.00 \%)$, while the potential of garlic $(-44.85 \%)$ was equivalent to rosuvastatin which was used as a comparison.
The results in the form of total-C levels after 14 days of treatment were presented in Figure 2. Data on the percentage reduction in total cholesterol in the treatment group were tested by one way ANOVA and obtained a p value $<0.05$. It means that at least there was a pair of treatment groups that have a significant difference.

Table 2 showed that Javanese ginger $(-15.16 \%)$, turmeric $(-14.02 \%)$, garlic $(-22.80 \%)$, and pomegranate flowers $(-65.24 \%)$ reduced total-C compared to controls with significant differences. The potential of garlic $(-22.80 \%)$ and pomegranate flowers $(-65.24 \%)$ in lowering total-C were better than rosuvastatin $(-18.70 \%)$, while the potential for Javanese ginger $(-15.16 \%)$ and turmeric $(-14.02 \%)$ equivalent to rosuvastatin which was used as a comparison.
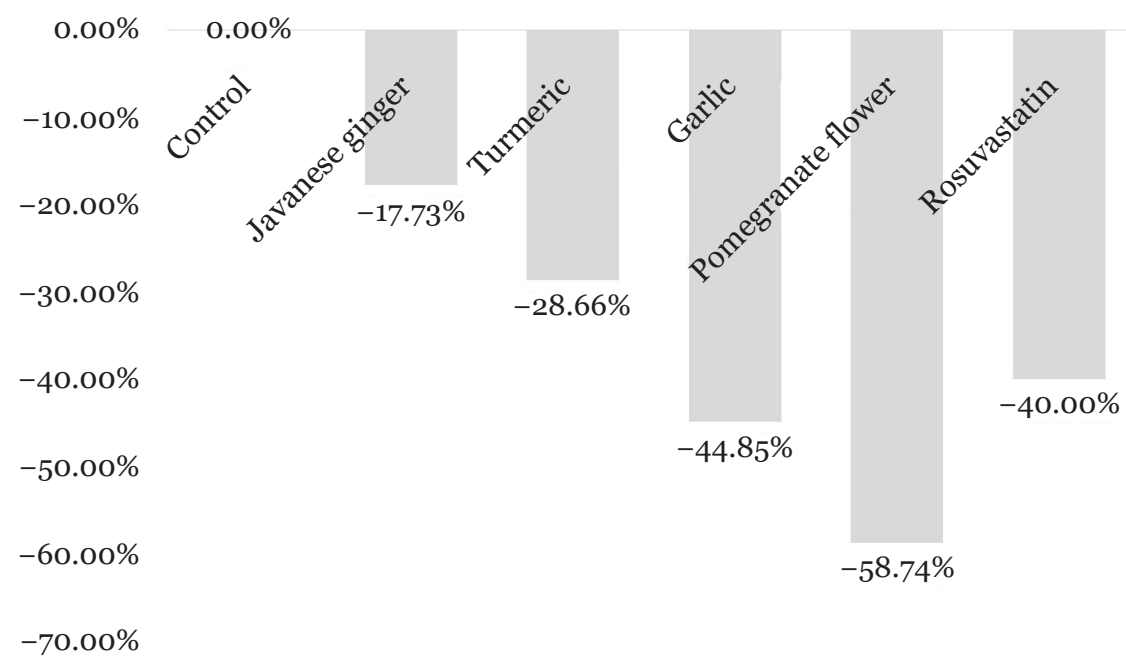

Figure 1 Percentage Reduction in LDL-C Compared to Controls

Table 1 LSD Test Results in Lowering LDL-C Data of the Six Treatment Group

\begin{tabular}{lcccccc}
\hline & Control & $\begin{array}{c}\text { Javanese } \\
\text { Ginger }\end{array}$ & Turmeric & Garlic & $\begin{array}{c}\text { Pomegranate } \\
\text { Flower }\end{array}$ & Rosuvastatin \\
& $\mathbf{0 . 0 0 \%}$ & $\mathbf{- 1 7 . 7 3 \%}$ & $\mathbf{- 2 8 . 6 6 \%}$ & $-\mathbf{4 4 . 8 5 \%}$ & $\mathbf{- 5 8 . 7 4 \%}$ & $\mathbf{- 4 0 . 0 0 \%}$ \\
\hline Control & & NS & NS & $* *$ & $* *$ & $* *$ \\
Javanese ginger & & & NS & $* *$ & $* *$ & $* *$ \\
Turmeric & & & & $* *$ & $* *$ & $*$ \\
Garlic & & & & & NS & NS \\
Pomegranate & & & & & & $*$ \\
flower & & & & & \\
Rosuvastatin & & & & & & \\
\hline
\end{tabular}




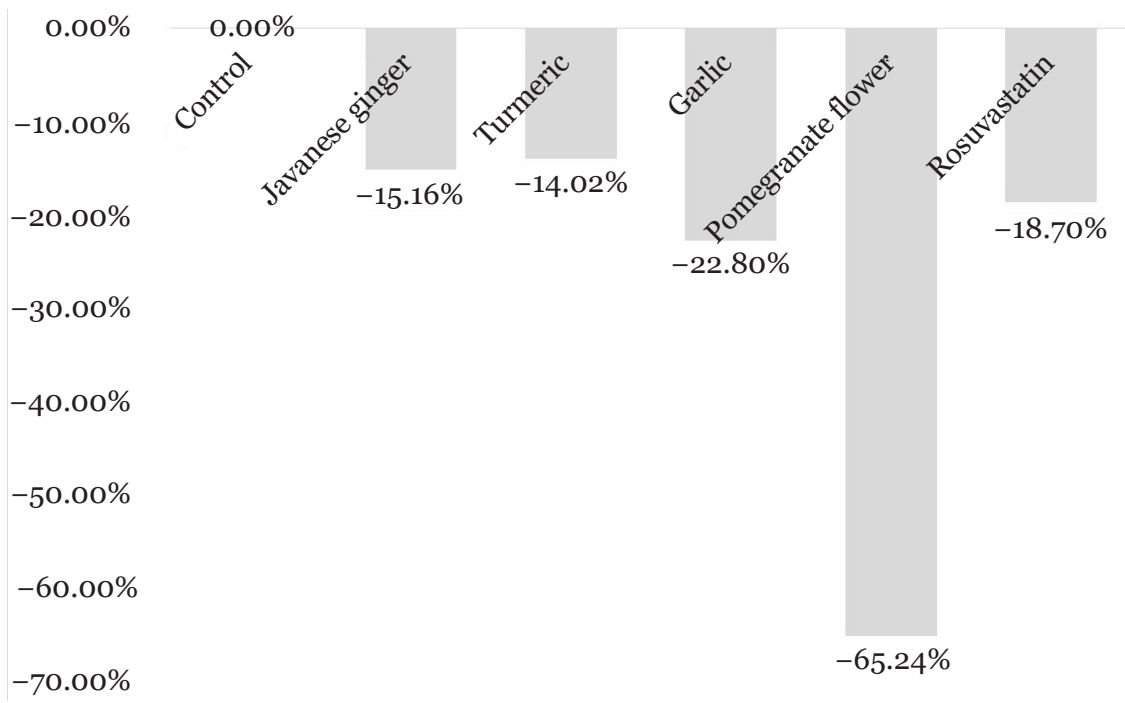

Figure 2 Percentage Reduction in Total-C Compared to Controls

Table 2 LSD Test Results in Lowering Total-C Data of the Six Treatment Group

\begin{tabular}{lcccccc}
\hline & Control & $\begin{array}{c}\text { Javanese } \\
\text { Ginger }\end{array}$ & Turmeric & Garlic & $\begin{array}{c}\text { Pomegranate } \\
\text { Flower }\end{array}$ & Rosuvastatin \\
& $\mathbf{0 . 0 0 \%}$ & $\mathbf{- 1 5 . 1 6 \%}$ & $\mathbf{- 1 4 . 0 2 \%}$ & $-\mathbf{2 2 . 8 0 \%}$ & $\mathbf{- 6 5 . 2 4 \%}$ & $\mathbf{- 1 8 . 7 0 \%}$ \\
\hline Control & & $* *$ & $* *$ & $* *$ & $* *$ & $* *$ \\
Javanese ginger & & & NS & $*$ & $* *$ & NS \\
Turmeric & & & & $*$ & $* *$ & NS \\
Garlic & & & & & $* *$ & $* *$ \\
Pomegranate & & & & & & \\
flower & & & & & & \\
Rosuvastatin & & & & & & \\
\hline
\end{tabular}

\section{Discussion}

This study showed that garlic and pomegranate flowers lowered LDL-C compared to the control with a significant difference. The potential of pomegranate flowers in lowered LDL-C is better than rosuvastatin. The potential for garlic is equivalent to rosuvastatin which was used as a comparison. In addition, Javanese ginger, turmeric, garlic, and pomegranate flowers reduced total-C compared to controls with significant differences. The potential of garlic and pomegranate flowers in lowering total-C is better than rosuvastatin. The potential for Javanese ginger and turmeric is equivalent to rosuvastatin which was used as a comparison.
The test materials for this study consisted of Javanese ginger, turmeric, garlic, and pomegranate flowers, each of which had been previously studied. Here are some studies that have been done before. Previous research of Javanese ginger with a $560 \mathrm{mg} / \mathrm{kg}$ BW showed a decrease in LDL-C and increased HDL-C with experimental mice. ${ }^{9}$ Research on herbal medicine containing Cassia sennae dried leaves, Sonchus arvensis dried leaves, Guazuma ulmifolia dried leaves, C. longa dried rhizomes, C. xanthorrhiza dried rhizomes, Camellia sinensis dried leaves, and Phyllanthus niruri dried herb in human research subjects have been done previously. This study showed a decrease in plasma cholesterol levels from $212.42 \mathrm{mg} / \mathrm{dL}$ to $196.6 \mathrm{mg} / \mathrm{dL}$ after 
28 days of treatment. ${ }^{4}$ The main content of Javanese ginger (Curcuma xanthorhiza Roxb.) is curcuminoid which in several studies has shown its role as an anti-hypercholesterolemic agent. ${ }^{10}$

The content of turmeric, which plays a role in reducing total cholesterol and LDL cholesterol, is curcumin. This main ingredient also has an antioxidant effect that maintains SOD activity. ${ }^{11}$ Research using curcumin can lower total cholesterol and LDL cholesterol and reduce cardiovascular disease risk. ${ }^{12}$ Curcuminoids are the main components, especially in turmeric, and the mechanism of action of turmeric is mainly through this curcumin. The pharmacological effects of curcuminoids include lowering cholesterol levels and also having a hypoglycemic effect. ${ }^{13}$ Research on turmeric effects conducted on human research subjects showed that a turmeric dose of 1 gram/day for 28 days reduced total cholesterol from 234.44 $\mathrm{mg} / \mathrm{dL}$ to $202.06 \mathrm{mg} / \mathrm{dL}^{14}$ Turmeric has antiadipogenesis potential by inhibiting the synthesis of triglycerides and cholesterol and inhibiting fat droplet formation in HepG2 cells. ${ }^{15}$ Another study with human research subjects, acute coronary syndrome patients, were administrating by low doses of curcumin showed a trend of decreasing total cholesterol and LDL cholesterol levels. ${ }^{16}$ Turmeric is a yellow spice with curcumin as its active ingredient. Turmeric affects Akt, growth factor, NF-kB, metastatic and angiogenic pathways. Turmeric also modulates cancer cells in humans, lowers the risk of cardiovascular disease, and suppresses inflammatory reactions. Turmeric also has antimicrobial, anti-obesity, prevents tumor formation, has antidepressant and anti-anxiety effects. ${ }^{17}$

Garlic has been used as a medicinal plant for thousands of years. Research shows garlic reduces total cholesterol levels by $7 \%$ and LDL cholesterol by $0.01 \%$ compared to controls. ${ }^{18}$ Garlic is known as an agent used for the prevention and treatment of cardiovascular diseases and metabolic diseases such as diabetes, dyslipidemia, and hypertension. Research has shown that the active ingredient of garlic, allicin, can reduce cholesterol, thereby reducing the risk of disease due to atherosclerosis. ${ }^{19}$ Garlic has active content, namely sulfur compounds, such as S-allyl cysteine, alliin, ajoene, and diallyl disulfide. This active ingredient has pharmacological effects. Some of the pharmacological effects of garlic include reducing the risk of cardiovascular disease, having antimicrobial, antioxidant effects, and reducing cancer risk. Previous research has shown that garlic lowers total cholesterol and LDL cholesterol but has no effect on HDL cholesterol and triglycerides..$^{20}$ Garlic with a dose of $900 \mathrm{mg} /$ day reduces total cholesterol and LDL cholesterol. Garlic can also be used for the prevention of oral thrush in children. ${ }^{21}$ Research on the effects of garlic with human research subjects in a village in Surabaya shows that consumption of four grams of garlic can reduce cholesterol levels and is recommended for hypercholesterolemia patients as a complementary therapy. ${ }^{22}$

Previous research has shown that consumption of pomegranate juice reduces LDL cholesterol and reduces oxidized LDL. The results showed reduced cholesterol accumulation in the cells and fewer foam cells. ${ }^{23}$ Pomegranate has antioxidant activity, both in infusion and in the form of ethanol extract. ${ }^{24}$ Previous research shows that giving pomegranate ethanol extract at a dose of $30 \mathrm{mg} / 200 \mathrm{~g} \mathrm{BW} /$ day for 15 days reduces LDL cholesterol levels. ${ }^{25}$

\section{Conclusions}

The conclusion is that garlic and pomegranate flowers lowered LDL-C and total-C, while Javanese ginger, turmeric, garlic, and pomegranate flowers reduced total-C.

\section{Conflict of Interest}

The authors have read the manuscript and agreed to submit it in its current form for publication in the journal. There are no conflicts of interest to declare.

\section{Acknowledgment}

This work was supported in part by a grant from the Lembaga Penelitian dan Pengabdian Masyarakat (LPPM) Universitas Kristen Maranatha and a grant from the Faculty of Medicine, Universitas Kristen Maranatha. Thank you to PT Sido Muncul for providing Javanese ginger, turmeric, and garlic ethanol extracts.

\section{References}

1. World Health Organization. Cardiovascular diseases (CVDs) [Internet]. Geneva, Switzerland: World Health Organization; 
2021 June 11 [cited 2021 June 30]. Available from: https://www.who.int/news-room/ fact-sheets/detail/cardiovascular-diseases(cvds).

2. Hussain MA, Mamun AA, Peters SA, Woodward M, Huxley RR. The burden of cardiovascular disease attributable to major modifiable risk factors in Indonesia. $\mathrm{J}$ Epidemiol. 2016;26(10):515-21.

3. Shepherd J, Barter P, Carmena R, Deedwania P, Fruchart JC, Haffner S, et al. Effect of lowering LDL cholesterol substantially below currently recommended levels in patients with coronary heart disease and diabetes: the treating to new targets (TNT) study. Diabetes Care. 2006;29(6):1220-6.

4. Zulkarnain Z, Triyono A, Novianto F. Jamu formula could reduce plasma cholesterol patients with mild hypercholesterolemia. Health Sci J Indones. 2018;9(2):87-92.

5. Kania A, Kharisma Y, Dewi MK. Bekatul (Oryza sativa L.) menghambar peningkatan kadar kolesterol darah. GMHC. 2014;2(1):3441.

6. Karimah F, Achmad S, Suganda RR. Efek jus buah naga super merah (Hylocereus costaricensis) dan simvastatin terhadap kadar kolesterol total darah dan bobot badan tikusjantan galur Wistar hiperkolesterolemia. GMHC. 2014;2(2):79-84.

7. Prawiradilaga RS, Shahib MN, Farimah SN. Perbedaan efek infusa bubuk kedelai (Glycine max), jamur tiram (Pleurotus ostreatus), dan campuran keduanya terhadap kadar kolestrol LDL, ekspresi gen reseptor LDL hati, dan berat omentum majus mencit model hiperlipidemia. GMHC. 2016;4(1):33-43.

8. Namazi F, Shomali T, Taghikhani P, Nazifi S. Protective effect of Urtica dioica leaf hydro alcoholic extract against experimentallyinduced atherosclerosis in rats. Avicenna $\mathrm{J}$ Phytomed. 2018;8(3):254-62.

9. Alipin K, Tanzania W, Kuntana YP. The effects of temulawak extract and yoghurt on HDL-LDL mice blood exposed waste cooking oil. In: Rahadian R, Aminin ALN, Darmawan A, Astuti Y, Huda MB, editors. Proceedings of $5^{\text {th }}$ International Seminar on New Paradigm and Innovation on Natural Sciences and Its Application ( $5^{\text {th }}$ ISNPINSA); 2015 October 7-8; Semarang, Indonesia. Semarang: Undip Press; 2016. p. 9-11.

10. Aznam N, Atun S. Pharmacological test of herbal products from temulawak (Curcuma xanthorhiza) as antihypercholesterol by in vivo. Int $\mathrm{J}$ Pharmacogn Phytochem Res. 2016;8(5);807-11.

11. Fikriah I. Effect of curcumin on the levels of total cholesterol, LDL cholesterol, the amount of F2-isoprostan and foam cell in aortic wall of rats with atherogenic diet. FMI. 2007;43(3):136-40.

12. Hussein SA, El-Senosi YA, Ragab MR, Hammad MMF. Hypolipidemic effect of curcumin in hyper-cholesterolemic rats. Benha Vet Med J. 2014;27(2):277-89.

13. Sukandar EY, Nurdewi, Elfahmi. Antihypercholesterolemic effect of combination of Guazuma ulmifolia Lamk. leave and Curcuma xanthorrhiza Roxb. rhizomes extract in Wistar rats. Int $\mathrm{J}$ Pharmacol. 2012;8(4):277-82.

14. Jatnika G, Hartanto S. Efforts in hypercholesterolemia treatment using turmeric (curcuminoid) extract phytotherapy on obese patients: preclinical study. JKP. 2018;6(3):227-34.

15. Budiman I, Tjokropranoto R, Widowati W, Fauziah N, Erawijantari PP. Potency of turmeric (Curcuma longa L.) extract and curcumin as anti-obesity by inhibiting the cholesterol and triglycerides synthesis in HepG2 cells. Int $J$ Res Med Sci. 2015;3(5):1165-71.

16. Alwi I, Santoso T, Suyono S, Sutrisna B, Suyatna FD, Kresno SB, et al. The effect of curcumin on lipid level in patients with acute coronary syndrome. Acta Med Indones. 2008;40(4):201-10.

17. Mughal MH. Turmeric polyphenols: a comprehensive review. Integr Food Nutr Metab. 2019;6(5):10.15761/IFNM.1000269.

18. Yeh YY, Liu L. Cholesterol-lowering effect of garlic extracts and organosulfur compounds: human and animal studies. $J$ Nutr. 2001;13(3)1:989S-93.

19. Lu Y, He Z, Shen X, Xu X, Jie F, Wu S, et al. Cholesterol-lowering effect of allicin on hypercholesterolemic ICR mice. Oxid Med Cell Longev. 2012:2012:489690.

20. Sun YE, Wang W, Qin J. Anti-hyperlipidemia of garlic by reducing the level of total cholesterol and low-density lipoprotein: a meta-analysis. Medicine (Baltimore). 2018;97(18):e0255.

21. Sharifi-Rad J, Silva NCC, Jantwal A, Bhatt 
ID, Sharopov F, Cho WC et al. Therapeutic potential of allicin-rich garlic preparations: emphasis on clinical evidence toward upcoming drugs formulation. Appl Sci (Basel). 2019;9(24):5555.

22. Maisaroh S, Zahro C, Puspitasari DR, Wahdi A, Pratiwi TF. Effective consumption of garlic (Allium sativum Linn) on decreasing blood cholesterol levels. IOP Conf Ser Earth Environ Sci. 2020;519:012004.

23. Anoosh E, Mojtaba E, Fatemeh S. Study the effect of juice of two variety of pomegranate on decreasing plasma LDL cholesterol. Proc
Soc Behav Sci. 2010;2(2):620-3.

24. Resti PV, Utami S, Arsyad. Antioxidant activity potential of red pomegranate (Punica granatum L.) peel as herbal tea. Mutiara Medika. 2020;20(2):79-84.

25. Wardani PM, Hawa H. A comparison between the effectiveness of the ethanol based extract of pomegranate peel (Punica granatum) and simvastatin drug for lowering blood LDL level in hypercholesterolemic male rats (Rattus novergicus). JKKI. 2015;7(2):46-51. 